\title{
High frequency callus induction and proliferation of MD2 pineapple (Ananas comosus)
}

\author{
${ }^{1}$ Salihan, A.N. and ${ }^{1,2^{*}}$ Yusuf, N.A. \\ ${ }^{1}$ Faculty of Plantation and Agrotechnology, Universiti Teknologi MARA, Cawangan Melaka, Kampus Jasin, \\ 77300 Merlimau, Melaka, Malaysia. \\ ${ }^{2}$ Agricultural Biotechnology Research Interest Group (RIG), Faculty of Plantation and Agrotechnology, \\ Universiti Teknologi MARA, Kampus Shah Alam, 40450 Shah Alam, Selangor, Malaysia
}

\author{
Article history: \\ Received: 23 July 2020 \\ Received in revised form: 10 \\ November 2020 \\ Accepted: 22 December 2020 \\ Available Online: 27 \\ December 2020
}

Keywords:

2,4-D,

BAP,

Callus induction,

MD2, pineapple

DOI:

https://doi.org/10.26656/fr.2017.4(S5).016

\begin{abstract}
Ananas comosus var. MD2 is currently the most preferred pineapple variety in the international market due to its pleasant aroma and high Brix acidity ratio. In vitro approaches such as callus culture is promising in producing disease-free plantlet. However, there are limited studies reported on callus culture of MD2 variety despite the potential of in vitro regeneration through biotechnological advances. The purpose of the study was to determine the effect of plant growth regulators (PGRs) i.e., 2,4dichlorophenoxyacetic acid (2,4-D), 6-benzylaminopurine (BAP) and Thidiazuron (TDZ) on callus induction from leaf explant of MD2 pineapple. Leaf base explants were cultured on Murashige and Skoog (MS) media supplemented with varying concentration of 2,4-D $(0.5$ to $6.0 \mathrm{mg} / \mathrm{L})$ alone and in combination with BAP $(1.0$ to $3.0 \mathrm{mg} / \mathrm{L})$. The frequency of callus induction was seen significantly highest $(91.67 \pm 8.33 \%)$ with maximum callus fresh weight $(0.25 \pm 0.07 \mathrm{~g})$ at a combination of $2.0 \mathrm{mg} / \mathrm{L} 2,4-\mathrm{D}$ and $2.0 \mathrm{mg} / \mathrm{L}$ BAP. The shortest duration of callus formation was seen on day 12 with the lowest concentration of 2,4-D, $0.5 \mathrm{mg} / \mathrm{L}$. There is a moderate correlation between the earliness of callus formation and the frequency of callus induction $(\mathrm{P}<0.01)$. The most favourable media for callus proliferation was $6.0 \mathrm{mg} / \mathrm{L} 2,4-\mathrm{D}$ and $2.0 \mathrm{mg} / \mathrm{L} \mathrm{TDZ}$ as the highest fresh weight of $1.52 \pm 0.03 \mathrm{~g}$ was recorded. Callus culture has the potential to be a source of plant material and secondary metabolites production. In this study, 2,4-D and BAP have successfully induced callus in MD2 pineapple.
\end{abstract}

\section{Introduction}

Pineapple is one of many commercial fruits available in the global market. Currently, MD2 is the most successful cultivar and listed as a key crop and known by its trade names as "Golden Ripe", "Super Sweet", "Rompine" or "Gold". According to United Nation Conference Trade and Development (UNCTAD, 2016), this variety was farmed in the early 1990s by Del Monte. Due to its deep and lasting transformation, the pineapple industry has been improved. This semi-spiny variety is able to establish as it has high yields and low sensitivity to black spots and soil parasites. Another characteristic of 'MD2' as reported by Thalip et al. (2015) is its mildly sweet in flavour making it very popular among consumers causing it to be one of the outstanding varieties produced for commercial purposes.

Among constraints faced in the production of pineapple is the cultivation of seedlings as the parent plant requires a significant length of time to produce slips and suckers. Biotechnology covers many fields like tissue culture and genetic engineering to the applications like an ideal tool for crop improvement (Bukhori and Khalid, 2013; Yusuf et al., 2016; Hossain and Uddin, 2017). Cytokinin and auxin or auxin alone are normally included in primary culture media for callus induction. Looking at the potential and promises of plant tissue culture technology, efforts have been directed for implementing this technology to improve the productivity of these plants (Wu et al., 2012). Keeping this in view, the present study will focus on callus formation involving PGRs.

The use of PGRs such as auxin with a combination of cytokinin show successful result for callus induction in different cultivars of pineapple (Akbar et al., 2003; De Silva et al., 2008; Hamid et al., 2013; Yusuf et al., 2016; 
Hossain and Uddin, 2017; Harahap et al., 2019). Yusuf et al. (2016) reported successful callus induction of MD2 pineapple supplemented with very high cytokinin to auxin ratio, $14 \mathrm{mg} / \mathrm{L}$ BAP, and $6 \mathrm{mg} / \mathrm{L}$ NAA. Thus, the present study aimed at improving protocol for callus induction of MD2 pineapple and proliferation with the use of a lower concentration of PGRs to become costeffective and affordable for industrial purposes without affecting the growth and potential of callus.

\section{Materials and methods}

\subsection{Plant materials}

A. comosus var. MD2 was purchased from MD2 pineapple plantation Lembah Matanaga Sdn Bhd, Ayer Hitam, Johor. The plantlets were regenerated from crown meristem preferably with 20 to $30 \%$ maturity.

\subsection{Preparation of sterile mother plant}

The leaves of the crown were removed (Figure 1a and $1 \mathrm{~b}$ ), thoroughly washed with detergents, and rinsed. In laminar airflow, the crown was immersed in $90 \%$ ethanol for 3 mins and rinsed. Then, it was sterilized in $60 \%$ Clorox for 20 mins with 2 drops of Tween 20 followed by $20 \%$ Clorox for 10 mins. The crown was again rinsed with sterile distilled water three to five times to ensure the remaining sterilant was washed completely. The crown meristem tip was excised 0.5 to $1.0 \mathrm{~cm}$ in size and cultured on solid MS media (Murashige and Skoog, 1962) supplemented with 2.0 $\mathrm{mg} / \mathrm{L}$ BAP. The cultures were incubated at $25 \pm 1^{\circ} \mathrm{C}$ under a 16/8-h light/dark photoperiod (25-30 $\mu \mathrm{mol}$ photons $\mathrm{m}^{-2} \mathrm{~s}^{-1}$ ) using a fluorescent lamp. The leaves obtained from two months old in vitro plantlet (Figure 1c) were used as the explant for callus induction.
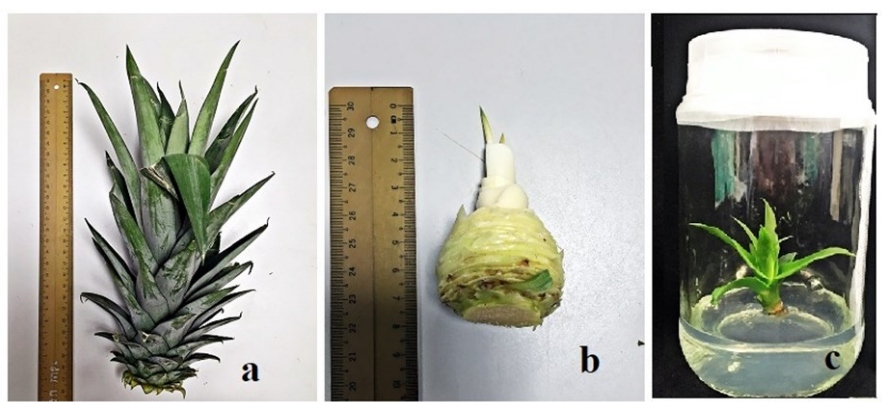

Figure 1. Sample explant of MD2 pineapple a: Crown of MD2 pineapple before removal of its leaves b: Crown of MD2 pineapple after removal of its leaves c: Regeneration of in vitro plantlet of MD2 pineapple after two months of culture from crown explant.

\subsection{Preparation of Callus Induction (CI) and Callus Proliferation (CP) media}

A volume of $1 \mathrm{~L}$ MS media was prepared by weighing $4.4 \mathrm{~g} / \mathrm{L}$ of MS media and $30 \mathrm{~g} / \mathrm{L}$ sucrose dissolved in $800 \mathrm{~mL}$ distilled water in a Schott bottle. After maintaining $\mathrm{pH}$ at 5.8, water volume was made up to $1 \mathrm{~L}$ and $2 \mathrm{~g} / \mathrm{L}$ of Gelrite, gelling agent was added to solidify the media. Thereafter, the media was autoclaved at $121^{\circ} \mathrm{C}$ for $20 \mathrm{mins}$. The hormone supplements were added as required for different treatments as followed:

CI Media: Control (MS medium without hormone) as shown in Table 1

$\mathrm{CP}$ Media: Control (MS medium without hormone) as shown in Table 2.

Table 1. Callus Induction (CI) Media

\begin{tabular}{cc}
\hline CI Media & Concentration $(\mathrm{mg} / \mathrm{L})$ \\
\hline $2,4-\mathrm{D}$ & 0 \\
Control & 0.5 \\
C1 & 1 \\
C2 & 2 \\
C3 & 4 \\
C4 & 6 \\
C5 & \\
$2,4-\mathrm{D}+$ BAP & $0.5+1.0$ \\
C6 & $1.0+1.0$ \\
C7 & $2.0+1.0$ \\
C8 & $4.0+1.0$ \\
C9 & $6.0+1.0$ \\
C10 & $0.5+2.0$ \\
C11 & $1.0+2.0$ \\
C12 & $2.0+2.0$ \\
C13 & $4.0+2.0$ \\
C14 & $6.0+2.0$ \\
C15 & $0.5+3.0$ \\
C16 & $1.0+3.0$ \\
C17 & $2.0+3.0$ \\
C18 & $4.0+3.0$ \\
C19 & $6.0+3.0$ \\
C20 &
\end{tabular}

Table 2. Callus Proliferation (CP) media

\begin{tabular}{cc}
\hline CP Media & Concentration of $2,4-\mathrm{D}+2.0 \mathrm{TDZ}(\mathrm{mg} / \mathrm{L})$ \\
\hline Control & 0 \\
P1 & 0.5 \\
P2 & 1 \\
P3 & 2 \\
P4 & 4 \\
P5 & 6 \\
P6 & 8 \\
\hline
\end{tabular}

\subsection{Callus induction}

Leaf base segments of two months old plantlet were excised aseptically into pieces (1.0 to $1.5 \mathrm{~mm}$ ) from the basal site and inoculated on the media fortified by $2,4-\mathrm{D}$ hormones of varying concentration $(0.5,1.0,2.0,4.0$, and $6.0 \mathrm{mg} / \mathrm{L})$ alone or in combination with BAP (1.0, 2.0 and $3.0 \mathrm{mg} / \mathrm{L}$ ). All cultures were incubated in the dark at $25 \pm 1{ }^{\circ} \mathrm{C}$ and subcultured every three weeks. A total of 21 treatments (including control on MS hormone 
-free media) were investigated. After 42 days, the frequency of callus induction (\%), fresh weight (FW) of callus (g), and duration of callus formation (days) was recorded before transferring in proliferation media. The cultures were incubated in the dark at $25 \pm 1{ }^{\circ} \mathrm{C}$ and subcultured every three weeks. The morphological changes such as type, texture, and colour of callus were recorded.

\subsection{Callus proliferation}

The callus $(0.2 \mathrm{~g})$ obtained from callus induction were inoculated at different 2,4-D concentration ( 0.5 , $1.0,2.0,4.0,6.0$ and $8.0 \mathrm{mg} / \mathrm{L})$ combined with constant TDZ $(2.0 \mathrm{mg} / \mathrm{L})$ to determine best media for callus proliferation. The cultures were incubated in the dark at $25 \pm 1^{\circ} \mathrm{C}$ and subcultured every three weeks. The FW of callus and morphological changes were documented.

\subsection{Statistical analysis}

The treatments were replicated six times in a Randomized Complete Block Design (RCBD). The frequency of callus induction, $\mathrm{FW}$ of callus, and duration of callus formation was analysed through one-way analysis of variance (ANOVA) using Statistical Package for Social Sciences (SPSS) version 25. One-way ANOVA was conducted on the variables with no significance $(\mathrm{P}>0.05)$ in terms of the interaction effect of the different PGRs on callus induction and proliferation. Duncan's multiple-range test $(\mathrm{P}<0.05)$ was used to determine the significant difference between the means. The correlations between parameters were analysed using the Pearson correlation test $(\mathrm{P}<0.01)$.

\section{Results and discussion}

\subsection{Sterile mother plant}

The most challenging stage in the pineapple micropropagation process was creating healthy and freecontaminant cultures. The pineapple explants were however very prone to the substances of sterilization. Most explants were found to be damaged throughout the sterilization process whether they were unusable by explants contaminated with fungi and bacteria or bleaching. A thorough selection of explants from pathogen-free parent plants together with an effective method of surface sterilization must be identified to achieve high survival. Therefore, preparation of a sterile mother plant part was performed to determine the impact of the concentration of sterilization materials specifically for crown pineapple variety MD2 to obtain viable culture. Notably high survival percent of explants $(88.89 \pm 0.52 \%)$ was observed in $60 \%$ Clorox while only $5.56 \pm 0.41 \%$ of mortality and contamination were recorded.

\subsection{Effect of plant growth regulators 2,4-D and BAP on callus induction}

Table 3 documents the effect of PGRs on callus

\begin{tabular}{|c|c|c|c|}
\hline $\begin{array}{l}\text { PGRs } \\
(\mathrm{mg} / \mathrm{L}) \\
\end{array}$ & $\begin{array}{l}\text { Frequency of Callus } \\
\text { Induction }(\%)\end{array}$ & $\begin{array}{l}\text { Fresh Weight of Callus } \\
(\mathrm{g})\end{array}$ & $\begin{array}{c}\text { Duration of Callus } \\
\text { Formation (days) }\end{array}$ \\
\hline Control & - & - & - \\
\hline $\mathrm{C} 1$ & $16.67 \pm 10.54^{\mathrm{fg}}$ & $0.02 \pm 0.03^{\mathrm{ij}}$ & $12.33 \pm 19.15^{\mathrm{d}}$ \\
\hline $\mathrm{C} 2$ & $41.67 \pm 15.37^{\mathrm{cd}}$ & $0.08 \pm 0.09^{\mathrm{i}}$ & $22.67 \pm 17.76^{\mathrm{abcd}}$ \\
\hline $\mathrm{C} 3$ & $83.33 \pm 10.54^{b}$ & $0.20 \pm 0.09^{c}$ & $27.33 \pm 1.97^{\mathrm{abc}}$ \\
\hline $\mathrm{C} 4$ & $83.33 \pm 10.54^{\mathrm{b}}$ & $0.21 \pm 0.10^{\mathrm{b}}$ & $26.83 \pm 1.83^{\mathrm{abc}}$ \\
\hline $\mathrm{C} 5$ & $66.67 \pm 10.54^{\mathrm{d}}$ & $0.14 \pm 0.05^{\mathrm{g}}$ & $30.00 \pm 2.68^{\mathrm{abc}}$ \\
\hline C6 & $25.00 \pm 11.18^{\mathrm{ef}}$ & $0.04 \pm 0.05^{\mathrm{hi}}$ & $19.17 \pm 18.44^{\mathrm{cd}}$ \\
\hline $\mathrm{C} 7$ & $50.00 \pm 12.91^{\mathrm{f}}$ & $0.12 \pm 0.08^{\mathrm{cd}}$ & $25.17 \pm 12.43^{\mathrm{abcd}}$ \\
\hline $\mathrm{C} 8$ & $50.00 \pm 12.91^{\mathrm{f}}$ & $0.11 \pm 0.07^{\mathrm{de}}$ & $23.33 \pm 11.45^{\mathrm{abcd}}$ \\
\hline C9 & $33.33 \pm 16.67^{\mathrm{g}}$ & $0.06 \pm 0.09^{\mathrm{gh}}$ & $12.33 \pm 13.63^{\mathrm{d}}$ \\
\hline $\mathrm{C} 10$ & $58.33 \pm 15.37^{\mathrm{e}}$ & $0.12 \pm 0.07^{\mathrm{cd}}$ & $26.00 \pm 12.76^{\mathrm{abcd}}$ \\
\hline $\mathrm{C} 11$ & $58.33 \pm 8.33^{\mathrm{e}}$ & $0.13 \pm 0.04^{\mathrm{h}}$ & $36.00 \pm 3.03^{\mathrm{a}}$ \\
\hline $\mathrm{C} 12$ & $58.33 \pm 8.33^{\mathrm{e}}$ & $0.10 \pm 0.05^{\mathrm{de}}$ & $36.33 \pm 0.82^{\mathrm{a}}$ \\
\hline $\mathrm{C} 13$ & $91.67 \pm 8.33^{\mathrm{a}}$ & $0.25 \pm 0.07^{\mathrm{a}}$ & $23.00 \pm 1.10^{\mathrm{abcd}}$ \\
\hline $\mathrm{C} 14$ & $75.00 \pm 11.18^{\mathrm{c}}$ & $0.17 \pm 0.05^{\mathrm{d}}$ & $19.17 \pm 0.98^{\mathrm{bcd}}$ \\
\hline $\mathrm{C} 15$ & $66.67 \pm 10.54^{\mathrm{d}}$ & $0.16 \pm 0.05^{\mathrm{e}}$ & $27.00 \pm 2.68^{\mathrm{abc}}$ \\
\hline $\mathrm{C} 16$ & $33.33 \pm 10.54^{\mathrm{g}}$ & $0.07 \pm 0.06^{\mathrm{fg}}$ & $23.17 \pm 17.96^{\mathrm{abcd}}$ \\
\hline $\mathrm{C} 17$ & $41.67 \pm 8.33^{\mathrm{cd}}$ & $0.11 \pm 0.06^{\mathrm{de}}$ & $26.33 \pm 12.94^{\mathrm{abcd}}$ \\
\hline $\mathrm{C} 18$ & $66.67 \pm 10.54^{\mathrm{d}}$ & $0.15 \pm 0.05^{\mathrm{bc}}$ & $26.33 \pm 0.82^{\text {abcd }}$ \\
\hline C19 & $75.00 \pm 11.18^{\mathrm{c}}$ & $0.17 \pm 0.06^{\mathrm{ab}}$ & $26.33 \pm 0.98^{\mathrm{abcd}}$ \\
\hline $\mathrm{C} 20$ & $58.33 \pm 8.33^{\mathrm{e}}$ & $0.15 \pm 0.04^{f}$ & $31.50 \pm 3.02^{\mathrm{ab}}$ \\
\hline
\end{tabular}

Values are expressed as mean \pm SD of 6 replicates for the incubation period of 6 weeks. Means followed by the same letter (within column) are not significantly different at $\mathrm{p} \leq 0.05$. Control $=\mathrm{MS}$ alone 
induction such as frequency of callus induction, $\mathrm{FW}$, and duration of callus formation. The results indicated that control media with the absence of PGRs failed to induce callus even after 42 days of inoculation, thereby affirming that PGRs were essential for callus induction in MD2 pineapple. Auxin 2,4-D used alone and in combination with BAP successfully induced callus. This is supported by Amin et al. (2005) where singly used of 2,4-D and combination with BAP for cultivar Giant Kew pineapple were effective for callus initiation. Conversely, a study conducted by De Silva et al. (2008) which 2,4-D failed to induce callus from meristematic globular bodies (MGB) in Moris and Josapine pineapple.

The auxin 2,4-D alone was capable to induce callus from the explant as early as 12 days of culture in $\mathrm{C} 1(0.5$ $\mathrm{mg} / \mathrm{L} \mathrm{2,4-D).} \mathrm{Meanwhile,} \mathrm{C3} \mathrm{(2.0} \mathrm{mg/L} \mathrm{2,4-D)} \mathrm{and} \mathrm{C4}$ $(4.0 \mathrm{mg} / \mathrm{L} 2,4-\mathrm{D})$ both displayed $83.33 \pm 10.54 \%$ of explant callusing $(\mathrm{P}<0.05)$. Among all the concentrations of 2,4-D tested in this study, C3 and C4 also displayed similarly high $\mathrm{FW}$ of callus with $0.20 \pm 0.09 \mathrm{~g}$ and $0.21 \pm 0.10 \mathrm{~g}$ respectively. The duration for callus formation was delayed as the concentration of 2,4-D were increased. Nevertheless, the frequency of callus induction and callus FW was increased when the concentration of 2,4-D was increased. However, an exceptional decrease for callus induction and callus $\mathrm{FW}$ in C5 $(6.0 \mathrm{mg} / \mathrm{L} 2,4-\mathrm{D})$ were recorded. A positive correlation was seen in callus induction and callus FW as analysed with Pearson's Correlation $(\mathrm{P}<0.01)$. The opposite was reported in different plant species, Coffea arabica Code 71 where increased induction rates documented with a lower concentration of 2,4- D (Mwaniki et al., 2019).

In a combination of treatments, the frequency of callus induction was significantly increased with the addition of cytokinin. Compared to all the treatments, C13 (2.0 mg/L 2,4-D + $2.0 \mathrm{mg} / \mathrm{L}$ BAP) recorded significantly highest callus induction $(91.67 \pm 8.33 \%)$ and maximum callus FW $(0.25 \pm 0.07 \mathrm{~g}) 23$ days of culture $(\mathrm{P}<0.05)$. The duration for callus formation in combination treatment, C12 $(1.0 \mathrm{mg} / \mathrm{L} 2,4-\mathrm{D}+2.0 \mathrm{mg} / \mathrm{L}$ BAP) was the longest with $36.33 \pm 0.82$ days. The results indicated that there was a moderate correlation $(\mathrm{P}<0.01)$ between the frequency of callus induction and the duration of callus formation. It was noted that an additional concentration of 2,4-D beyond $4 \mathrm{mg} / \mathrm{L}$ suppressed the rise in frequency of callus induction and FW of callus simultaneously.

The inclusion of auxin in cell culture media has been reported in various plant species including pineapple (Rahayu et al., 2016; Mahadi et al., 2017; Harahap et al., 2019). Auxin plays a significant role in the initiation of callus, but it relies on the type and concentration used in culture media (Wahyuni et al., 2017). Different types of auxin caused different effects on the plants as the responses were highly dependent on plant genotypes and culture conditions (Budisantoso et al., 2017; Mwaniki et al., 2019). For records, auxin 2,4-D has been successfully and widely used in tissue culture due to its strong and significant effect on callus differentiation (Fazeli-Nasab, 2018). The optimum concentration of 2,4$\mathrm{D}$ enhanced the growth and biomass of pineapple as proven by Amin et al. (2005). Results obtained in this experiment were in accordance with previous studies of various pineapple cultivars such as Sipahutar (Harahap et al., 2019), Smooth Cayenne (Istiqomah and Shofi, 2018), and in Tangkit (Zulkarnain and Neliyati, 2017).

Excessive concentrations of 2,4-D in the culture media inhibited the growth and development of MD2 pineapple (Hamid et al., 2013). Such concentrations retarded the rate of protoplasmic streaming and highly toxic for shoot and bud (Thimann, 1939). The common occurrence caused by extremely high auxin were abnormality of shoots and stunted culture (Bukhori and Khalid, 2013). Inadequate supply of oxygen, water, and minerals to the cell obstructed plant growth (Budisantoso et al., 2017). Furthermore, an oversupply of 2,4-D caused a longer duration of callus formation and this result was in agreement with Akbar et al. (2003). An application of a high concentration of exogenous PGRs to accelerate the duration of callus formation was restricted by endogenous PGRs produced by the plant itself. Thus, causing the competition between both exogenous and endogenous PGRs which consequently hindered the normal expression of callus formation (Wahyuni et al., 2017).

Initially, cytokinin promoted organogenesis and cell division where in most cases aided callus induction (Adil et al., 2018; Mwaniki et al., 2019). Combination of PGRs encouraged callus induction as well as shoot multiplication in pineapple (Yusuf et al., 2016; Zulkarnain and Neliyati, 2017; Hossain and Uddin, 2017). According to Indah and Ermavitalini (2013), FW physiologically contains two components, namely water and carbohydrates. The amount of FW generated depends significantly on how rapidly these cells divide, multiply, and then develop the callus (Wahyuni et al., 2017). The result obtained in this study was in agreement with Harahap et al. (2019) where balanced auxin and cytokinin ratio significantly effective in callus initiation of Sipahutar pineapple grown in Indonesia and lead to the highest fresh and dry weight of callus. This suggests that a balanced ratio of 2,4-D and BAP were rather favourable in callus induction of MD2 pineapple. In this sense, current findings were able to improve the protocol proposed by Yusuf et al. (2016). 
The duration of callus formation indicated the time taken for swelling to explant from the cut to form the callus (Rahayu et al., 2016). The presence of cytokinin BAP was insignificant to accelerate the duration of callus formation. As 2,4-D concentration was increased, the callus formation was further delayed. Conversely, Mahadi et al. (2016) reported addition of cytokinin speed up callus formation as well as when 2,4-D concentration was increased. Nevertheless, application of BAP to the culture media significantly increased $(\mathrm{P}<0.05)$ callus induction and callus FW despite a longer duration of callus formation. Time is a critical factor in the determination of effective induction protocols. However, complementary factors together with callus induction frequency, callus biomass, and callus morphology were essential (Mwaniki et al., 2019).

The selection of the best explants for callus induction has been the most critical factor in the micropropagation of many plant species (Bukhori and Khalid, 2013). Callus induction cultured from crown explant took nine weeks of culture for callus formation. Meanwhile, leaf base explant was selected as it took as early as three weeks of culture to produce callus. Moreira et al. (2016) stated that in vitro leaf base explants of Ananas erectifolius were effective for maximum callus induction with a white or creamy coloured base of young leaves. De Silva et al. (2008) acknowledged that the leaf base contains a meristematic region for cell division and enlargement.

Figure 2 shows morphological changes of explant at one week, four weeks, and six weeks after culture. The explant was seen swelling after the first week of culture (Figure 2a) and began to multiply at the wounded site four weeks after culture (Figure 2b). An unorganized clump of white tissue was seen covering the surface of the explant and significantly enlarged after 6 weeks of culture (Figure 2c). Most of the callus exhibited compact texture. Callus demonstrated from this experiment were heavily lignified and hard in texture (compact), whereas others break easily into small fragments (friable). A mixture of compact and friable callus was recorded in a combination of treatments.

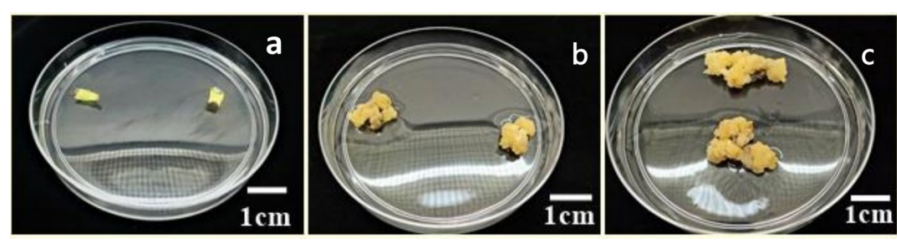

Figure 2. Induction of callus from in vitro leaf base explant a: Explant after 1 week of culture b: Explant after 4 weeks of culture c: Explant after 6 weeks of culture

Most pineapple callus produced under supplementation of 2,4-D were compact in texture
(Akbar et al., 2003; Amin et al., 2005; Harahap et al., 2019). Recently Harahap et al. (2019) documented compact callus with the inclusion of BAP to the culture media. Compact textured callus occurred due to water potential absorption into the cell which caused it to become rigid (Nasution and Nasution, 2019). Furthermore, auxin also increased the con-centration of intracellular fluid by stimulating the accrual of material structure and chemical component in the cytoplasm (Budisantoso et al., 2019). This was contrary to the experiment by Yusuf et al. (2016) where friable callus was distinguished with a combination of BAP. Despite strong activities to stimulate differentiation, the growth of the callus was sustained proficiently with 2,4-D hormone (Wahyuni et al., 2017).

Since the callus was treated in the dark, the colour of the callus was limited to yellowish white and yellowishbrown after 42 days of completed callus formation. Increased 2,4-D concentration resulted in browning of callus. The addition of BAP to the culture media improved the colour of the callus. After four subcultures, the yellowish-brown callus turned brown completely. Actively dividing callus was usually white, yellow, and green in colour (Nasution and Nasution, 2019). Auxin in the culture media accumulated ethylene (native plant hormone) often caused browning of culture (Rahayu et al., 2016). The presence of secondary metabolites, long incubation time without subculture and age of callus were factors that caused the browning and necrosis of culture (Budisantoso et al., 2017). As the nutrient in the culture media depleted, an increase in carbon dioxide $(\mathrm{CO} 2)$ and limited oxygen $(\mathrm{O} 2)$ resulted in anoxia (Fazeli-Nasab, 2018).

The explant response towards different concentrations of PGRs produced different degrees of callusing; slight callus, moderate callus, and profuse callus (Table 4). The callus response differed according to concentration and combination of PGRs supplemented in the culture media. Profuse callus occurred in a higher frequency of callus induction. Meanwhile, slight callus was observed in the lower frequency of callus induction. Previous studies have reported contradicting outcomes in where the callus was often varied in colour which is largely contributed by the absorption of light in the cell (Harahap et al., 2019). Similar results testified by Mahadev et al. (2014) profuse and compact callus presented with the use of a higher concentration of 2,4D. Profuse and compact callus recognized as good callus by Indah and Ermavitalini (2013) as it can accumulate secondary metabolites. 
Table 4. Effect of PGRs on Morphological Changes of Explant, $n=6$

\begin{tabular}{cccc}
\hline PGRs (mg/L) & Texture & Colour & Explant Response \\
\hline Control & - & - & Browning \\
C1 & Compact & Yellowish brown & Slight callus \\
C2 & Compact & Yellowish white & Slight callus \\
C3 & Compact & Yellowish white & Profuse callus \\
C4 & Compact & Yellowish brown & Profuse callus \\
C5 & Compact & Yellowish brown & Profuse callus \\
C6 & Compact & Yellowish white & Slight callus \\
C7 & Compact & Yellowish white & Moderate callus \\
C8 & Compact & Yellowish white & Moderate callus \\
C9 & Compact & Yellowish white & Slight callus \\
C10 & Compact & Yellowish brown & Moderate callus \\
C11 & Compact & Yellowish white & Moderate callus \\
C12 & Compact & Yellowish white & Moderate callus \\
C13 & MIxture compact and friable & Yellowish white & Profuse callus \\
C14 & MIxture compact and friable & Yellowish brown & Profuse callus \\
C15 & Compact & Yellowish brown & Profuse callus \\
C16 & Compact & Yellowish white & Moderate callus \\
C17 & Compact & Yellowish white & Moderate callus \\
C18 & Compact & Yellowish white & Moderate callus \\
C19 & Compact & Yellowish white & Profuse callus \\
C20 & Compact & Yellowish brown & Moderate callus \\
\hline
\end{tabular}

Control $=$ MS alone.

3.3 Effect of combination2,4-D and TDZ on callus proliferation

Table 3 shows the effect of PGRs concentration and combination on callus proliferation. The initial weight of callus inoculated on proliferation media was $0.20 \mathrm{~g}$ and the FW of callus was collected after 21 days. The maximum FW of callus was observed in P5, $1.52 \pm 0.03 \mathrm{~g}$ with a mixture of compact and friable texture. The lowest FW of callus was seen in $\mathrm{P} 1,0.29 \pm 0.01 \mathrm{~g}$ with a compact texture. The results suggested that $\mathrm{FW}$ of callus increased when the concentration of 2,4-D increased up to $6.0 \mathrm{mg} / \mathrm{L}$. Auxin 2,4-D and cytokinin TDZ was shown to give a synergistic effect with an increased FW of callus. Higher FW may be related to an increase in the concentration of cytosolic calcium caused by enhanced media absorption due to the use of higher PGRs. (Ngomuo et al., 2013).

Shoot and root (Figure 4a), as well as rooty callus (Figure 4b) and shooty callus (Figure 4c), were demonstrated from inoculation on different $\mathrm{CP}$ media. Concentration and combination of 2,4-D and TDZ instigated the morphological differences in callus. Higher 2,4-D concentration, P6 (8.0 mg/L 2,4-D and 2.0 $\mathrm{mg} / \mathrm{L}$ TDZ) produced root while lower 2,4-D concentration (P1, P2, P3 and P4) documented shoot from callus. P5 $(6.0 \mathrm{mg} / \mathrm{L} 2,4-\mathrm{D}$ and $2.0 \mathrm{mg} / \mathrm{L} \mathrm{TDZ})$ exhibited exceptionally stable callus formation without cell differentiation and organogenesis. The most optimum media for callus proliferation were determined by the highest FW of callus and based on the result from the experiments, P5 media was chosen. The media with no PGRs acted as a control revealed shoot and root formation after 6 weeks.
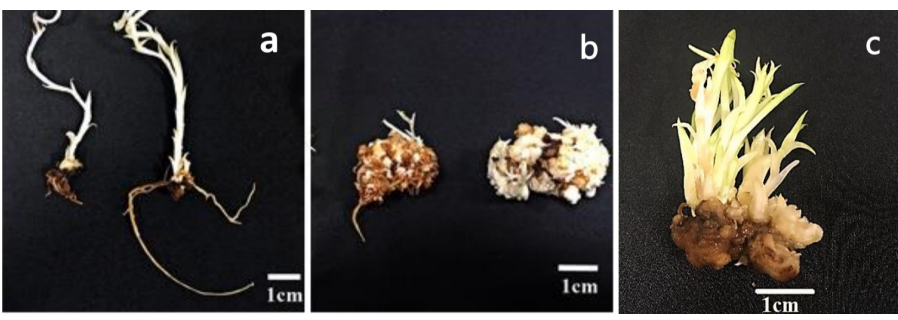

Figure 4. Callus responses in CP media a: Elongated shoot and root formation in control media after 6 weeks of culture. b: Rooty callus in P6 media and shooty callus in P3 media after 6 weeks of culture. c: Multiple shoot formation from callus inoculated on P1 proliferation media after 6 weeks of culture.

Callus growth was frequently associated with callus biomass (Kumlay and Ercisli, 2015) as an increment in callus FW was due to a high number of cells from cell division and enlarged cell size (Wahyuni et al., 2017). However, $8.0 \mathrm{mg} / \mathrm{L}$ 2,4-D restricted further increase of callus FW. The results corroborated with Adil et al. (2018) for in vitro grown herbaceous plant Cnidium officinale where biomass was increased from 2.3 to 13 $\mathrm{mg} / \mathrm{L}$ 2,4-D and any higher concentration of 2,4-D showed low biomass in callus. TDZ unusually induced a 30 -fold increase in the growth of callus cultures over other PGRs (Pai and Desai, 2018). Figure 3a 
demonstrated a mixture of compact and friable callus in CP media, P3 (2.0 mg/L 2,4-D and $2.0 \mathrm{mg} / \mathrm{L}$ TDZ) under a light microscope after 6 weeks of culture. The arrow in Figure $3 \mathrm{~b}$ indicated organ regeneration in $\mathrm{P} 1(0.5 \mathrm{mg} / \mathrm{L}$ 2,4-D and $2.0 \mathrm{mg} / \mathrm{L} \mathrm{TDZ}$ ).

Auxin and cytokinin may interact through synergistic, antagonistic, and additive mechanisms relying on inoculated tissue culture conditions that promote developmental decision towards callogenesis or shoot formation (Rasud and Bustamam, 2020). CP media fortified with different concentrations of 2,4-D with a combination of TDZ mostly produced compact callus (Table 5). Similar cases were documented by Zulkarnain and Neliyati (2017) whereby a compact structure has good regeneration ability and could be used easily for the shoot and root proliferation. The significance of TDZ has been reported in the callus of various plant cultures, which has also demonstrated a higher rate of cell proliferation and shoot multiplication compared to other PGRs (Budisantoso et al., 2017; Mwaniki et al., 2019).

Colour changes in callus that occurred during the 6week observation indicated a change in the growth phase and the regeneration control of the cells (Amin et al., 2005; De Silva et al., 2008; Ngomuo et al., 2013) The colour of yellowish-white and yellowish-brown showed that cells were still actively dividing (cleavage stage), while the colour of brown showed symptoms of ageing cells (Budisantoso et al., 2017; Nasution and Nasution, 2019). Rasud and Bustamam (2020) state the colour of the callus describes its visual appearance that indicates the activity level of a cell division. Type, concentration, and combination of auxin and cytokinin effects on callus morphology were discussed by several authors in plant tissue culture studies (Hossain and Uddin, 2017; Istiqomah and Shofi, 2018).

Auxin and cytokinin were both essential for in vitro cell proliferation. Moreover, it was discovered that the ratio of these PGRs determines the morphogenetic where high and low ratios of cytokinin to auxin favoured shoot and root regeneration, respectively (Hamid et al., pathway that the in vitro cultured tissue will follow

2013; Zulkarnain and Neliyati, 2017). Meanwhile, balanced concentrations were ideal in the growth of an unorganized cell mass (Akbar et al., 2003; Amin et al., 2005)

\section{Conclusion}

PGRs used in this study successfully induced and proliferated callus from MD2 pineapple. The most favourable media for callus induction was MS media supplemented with $2.0 \mathrm{mg} / \mathrm{L} 2,4-\mathrm{D}$ and $2.0 \mathrm{mg} / \mathrm{L}$ BAP. However, in light of cost efficiency, $2.0 \mathrm{mg} / \mathrm{L}$ of $2,4-\mathrm{D}$ alone would be sufficient to induce callus. Callus proliferated in this study was 5 times more than the initial inoculated weight in 21 days. Further studies should be established to determine the potential of pineapple callus in secondary metabolite production using biotechnological approach. The results could be used for large-scale commercial production of protease enzyme in pineapple.

\section{Conflict of interest}

The authors declare no conflict of interest.

\section{Acknowledgments}

This study was financially supported by the 600/ IRMI 5/3 GIP (015/2019) facilitated by Research Management Institute Teknologi MARA (UiTM) Shah Alam, Selangor, Malaysia. The authors gratefully acknowledge the facilities provided by Postgraduate Laboratory Faculty of Plantation and Agrotechnology, Universiti Teknologi MARA, Puncak Alam Selangor Malaysia throughout this research.

\section{References}

Adil, M., Ren, X., Kang, D.I. and Jeong, B.R. (2018). Effect of explant type and plant growth regulators on callus induction, growth and secondary metabolites production in Cnidium officinale Makino. Molecular Biology Reports, 45(6), 1919-1927. https:// doi.org/10.1007/s11033-018-4340-3

Table 5. Effect of PGRs on Callus Proliferation Parameters, $n=6$

\begin{tabular}{ccccc}
\hline PGRs (mg/L) & Fresh Weight of Callus $(\mathrm{g})$ & Texture & Colour & Response \\
\hline Control & - & - & - & Root and shoot formation \\
P1 & $0.29 \pm 0.01^{\mathrm{e}}$ & Compact & Yellowish white & Shoot formation \\
P2 & $0.40 \pm 0.01^{\mathrm{d}}$ & Compact & Yellowish white & Microshoot formation \\
P3 & $0.57 \pm 0.04^{\text {cd }}$ & Compact & Yellowish white & Shooty callus \\
P4 & $1.04 \pm 0.04^{\mathrm{b}}$ & Compact & Yellowish white & Shooty callus \\
P5 & $1.52 \pm 0.03^{\mathrm{a}}$ & Mixture of compact and friable & Yellowish white & Semi friable callus \\
P6 & $0.64 \pm 0.02^{\text {cd }}$ & Compact & Yellowish white & Rooty callus \\
\hline
\end{tabular}

Values are expressed as mean \pm SD of 6 replicates for the incubation period of 3 weeks. Values with the same superscript letter within the column are not significantly different at $p<0.05$. Control $=$ MS alone. 
Akbar, M.A., Karmakar, B.K. and Roy, S.K. (2003). Callus Induction and High-frequency Plant Regeneration of Pineapple (Ananas comosus (L.) Merr.). Plant Tissue Culture, 13(2), 109-116.

Amin, M.N., Rahman, M.M., Rahman, K.W., Ahmed, R., Hossain, M.S. and Ahmed, M.B. (2005). Large scale plant regeneration in vitro from leaf-derived callus cultures of pineapple (Ananas comosus L. Merr. cv. Giant Kew). International Journal of Botany, 1(2), 128-132. https://doi.org/10.3923/ ijb.2005.128.132

Budisantoso, I., Amalia, N. and Kamsinah, K. (2017). In vitro callus induction from leaf explants of Vanda $\mathrm{sp}$. stimulated by 2, 4-D. Biosaintifika: Journal of Biology and Biology Education, 9(3), 492-497. https://doi.org/10.15294/biosaintifika.v9i3.11018

Bukhori, M.M. and Khalid, N. (2013). Potential embryogenic callus induction protocol through cell suspension culture for high frequency plant regeneration of Maspine pineapple (Ananas comosus L.). Borneo Journal of Resource Science and Technology, 3(2), 40-45. https://doi.org/10.33736/ bjrst.245.2013

De Silva, A.E., Kadir, M.A., Aziz, M.A. and Kadzimin, S. (2008). Callus induction in pineapple Moris and Josapine. International Journal of Agricultural Research, 3(4), 261-267. https://doi.org/10.3923/ ijar.2008.261.267

Fazeli-Nasab, B. (2018). The effect of explant, BAP and 2, 4-D on callus induction of Trachyspermum ammi. Potravinarstvo Slovak Journal of Food Science, 12 (1), 578-586.

Hamid, N.S., Bukhori, M.F.M. and Jalil, M. (2013). Direct and indirect plant regeneration of pineapple var MD2 (Ananas comosus L.). Malaysia Applied Biology, 42(1), 61-66. https://doi.org/10.5219/953

Harahap, F., Diningrat, D.S., Poerwanto, R., Nasution, N.E.A. and Hasibuan, R.F.M. (2019). In vitro callus induction on Sipahutar pineapple (Ananas comosus L.) from North Sumatra Indonesia. Pakistan Journal of Biological Sciences, 22(11), 518-526. https:// doi.org/10.3923/pjbs.2019.518.526

Hossain, A.S. and Uddin, M.M. (2017). Callus cell, shoot and stem proliferation data from pineapple crown and banana inflorescence in vitro: Biochemical and antioxidant properties. Data in Brief, 10, 340-345. https://doi.org/10.1016/ j.dib.2016.11.097

Indah, P.N. and Ermavitalini, D. (2013). Induction of calligraphy leaf (Calophyllum inophyllum Linn.) In several combinations of 6-Benzylaminopurine (BAP) concentrations and 2, 4-
Dichlorophenoxyacetic Acid (2, 4-D). Journal of Science and ITS Arts, 2(1), 1-6.

Istiqomah, N. and Shofi, M. (2018). Response of pineapple callus (Ananas comosus Merr.) through invitro colchicines treatment. Scientiae Educatia: Jurnal Pendidikan Sains, 7(1), 1-10. https:// doi.org/10.24235/sc.educatia.v7i1.1919

Kumlay, A.M. and Ercisli, S. (2015) Callus induction, shoot proliferation and root regeneration of potato (Solanum tuberosum L.) stem node and leaf explants under long-day conditions, Biotechnology and Biotechnological Equipment, 29(6), 1075-1084. https://doi.org/10.1080/13102818.2015.1077685

Mahadev, M.D., Panathula, C.S. and Naidu, C.V. (2014). Efficient protocol for in vitro callus induction and indirect plant regeneration of Solanum viarum (Dunal) an important anticancer medicinal plant. International Journal of Medicinal and Aromatic Plants, 4(2), 117-123.

Mahadi, I., Syafi'i, W. and Sari, Y. (2017). Induction of musk orange callus (Citrus microcarpa) using hormones 2, 4-D and BAP by in vitro method. Indonesian Agricultural Science Journal, 21 (2), 84-89. https://doi.org/10.18343/jipi.21.2.84

Moreira, C., Andrade, H., Bertolucci, S., Lameira, O., Mohammed, A. and Pinto, J.E. (2016). Plantlet regeneration from young leaf segments of curaua (Ananas erectifolius), an Amazon species. Turkish Journal of Biology, 40(6), 1227-1234. https:// doi.org/10.3906/biy-1601-56

Murashige, T.F. and Skoog, A. (1962). A revised media for rapid growth and bioassays with tobacco tissue cultures. Physiologia Plantarum, 15, 473-479. https://doi.org/10.1111/j.1399-3054.1962.tb08052.x

Mwaniki, W.I., Lubabali, A.H., Asava, K.K., Agwanda, C.O. and Anami, S.E. (2019). Effects of genotype and plant growth regulators on callus induction in leaf cultures of Coffea arabica L. F1 hybrid. African Journal of Biotechnology, 18(31), 1004-1015. https://doi.org/10.5897/AJB2019.16913

Nasution, N.H. and Nasution, I.W. (2019). The effect of plant growth regulators on callus induction of mangosteen (Garcinia mangostana 1.). IOP Conference Series: Earth and Environmental Science, 305(1), 2049. https://doi.org/10.1088/17551315/305/1/012049

Ngomuo, M., Mneney, E. and Ndakidemi, P. (2013). The effects of auxins and cytokinin on growth and development of (Musa sp.) var. "Yangambi" explants in tissue culture. American Journal of Plant Sciences, 4(11), 2174. https://doi.org/10.4236/ ajps.2013.411269 
Pai, S.R. and Desai, N.S. (2018). Effect of TDZ on various plant cultures. In Ahmad, N. and Faisal, M. (Eds.) Thidiazuron: From urea derivative to plant growth regulator, p. 439-454. Singapore: Springer. https://doi.org/10.1007/978-981-10-8004-3_25

Rahayu, S., Roostika, I. and Bermawie, N. (2016). The effect of types and concentrations of auxins on callus induction of Centella asiatica. Nusantara Bioscience, 8(2), 283-287. https://doi.org/10.13057/ nusbiosci/n080224

Rasud, Y. and Bustaman, B. (2020). Induction of in vitro callus from clove leaves (Syizigium aromaticum L.) in media with various concentrations of auxin. Indonesian Agricultural Science Journal, 25(1), 6772. https://doi.org/10.18343/jipi.25.1.67

Thalip, A.A., Tong, P.S. and Ng, C. (2015) The MD2 'Super sweet' pineapple (Ananas comosus). UTAR Agriculture Science Journal, 1(4), 14-17.

Thimann, K.V. (1939). Auxins and the inhibition of plant growth. Biological Reviews, 14(3), 314-337. https:// doi.org/10.1111/j.1469-185X.1939.tb00937.x

United Nations Conference on Trade and Development. (2016). Pineapple. Retrieved from United Nations Conference on Trade and Development website: https://unctad.org/en/PublicationsLibrary/

INFOCOMM_cp09_Pineapple_en.pdf

Wahyuni, D.K., Andriani, P., Ansori, A.N.M. and Utami, E.S.W. (2017). Callus induction of gendarussa (Justicia gendarussa) by various concentration of 2, 4-D, IBA, and BAP. Biosaintifika: Journal of Biology and Biology Education, 9(3), 402-408. https://doi.org/10.15294/biosaintifika.v9i3.11347

Wu, S.Y., Hu, W., Zhang, B., Liu, S., Wang, J.M. and Wang, A.M. (2012). Bromelain ameliorates the wound microenvironment and improves the healing of firearm wounds. Journal of Surgical Research, 176(2), 503-509. https://doi.org/10.1016/ j.jss.2011.11.1027

Yusuf, N.H.M., Latip, M.A. and Kumar, S.V. (2016). Efficient protocol for plant regeneration and from callus cultures and Agrobacterium transformation of MD2 pineapple. Transactions of Persatuan Genetik Malaysia, 3, 137-141.

Zulkarnain, Z. and Neliyati, N. (2017). The effect of NAA and BAP on tissue culture of Tangkit pineapple (Ananas comosus (L.) Merr. cv. Tangkit). Biospecies, 10(1), 1-10. https:// doi.org/10.22437/biospecies.v10i1.3480 